Biol Neonate 1989;55:I-VI

\title{
Contents, Vol. 55, 1989
}

No. 1 Perinatal Epidemiology and Health Care Organisation: The Case of Belgium

Foreword 5

Perinatal Health in Belgium: An Introduction

Buekens, P.; Derom, R.; De Wals, P 6

Perinatal Mortality and Morbidity

Perinatal Mortality in Belgium

De Wals, P.; Bertrand, F.; Verlinden, M.; Beckers, R

Perinatal Morbidity in Belgium

Lagasse, R.; Devlieger, H.; De Wals, P.; Casaer, P.; Eggermont, E.; Lechat, M.F. ... 19 Maternal Mortality and Morbidity in Belgium

MacGillivray, I.; Spitz, B.; De Wei, M.; Van Assche, A 30

Perinatal Geography of Belgium

Vandenbussche, P.; Dujardin, B.; Wollast, E 34

Social Inequalities in Perinatal Health

Masuy-Stroobant, G 42

Perinatal Care

History of Prenatal Care in Belgium

Bande-Knops, J.; Renaer, M.; VanTongelen, E 50

Organization of Prenatal Care in Belgium

Humblet, P.C; Wollast, E.; Vandenbussche, P.; Leleux, P.; Buekens, P 55

Organization of Obstetrical Care in Belgium

Derom, R.; Pelfrene, E.; Vlietinck, R.; Thiery, M 63

Organization of Neonatal Care in Belgium

Van Reempts, P.; Senterre, J 70

Author Index 76

Subject Index 76

IV Contents

No. 2 Editorial

Arterial Hypertension in the Newborn Infant

Guignard, J.-P.; Gouyon, J.-B.; Adelman, R.D

Original Paper

Randomized Trials of Perinatal Interventions in Belgium and Europe

Alexander, S 84

Frequency of Cesarean Deliveries in Belgium

Thiery, M.; Derom, R.; Buekens, P 90

Effect of Light on Diurnal Variation of Blood Amino Acids in Neonates

Mantagos, S.; Moustogianni, A.; Varvarigou, A.; Frimas, C 97

Is Dietary Epidermal Growth Factor Absorbed by Premature Human Infants?

Gale, S.M.; Read, L.C.; George-Nascimento, C; Wallace, J.C.; Ballard, F.J104 
Effect of the Beta-Agonist Cimaterol on Growth and Composition of Neonatal Rats

Selected for Large and Small Body Size

Chromiak, J.A.; Mulvaney, D.R.; Strength, D.R Ill

Mode of Bilirubin Deposition in the Cerebellum of Developing Jaundiced Gunn Rats.

(With 1 color plate)

Aono, S.; Semba, R.; Sato, H.; Kashiwamata, S

Bile Secretory Apparatus in the Newborn Dog: Relationship between Structural and Functional Immaturities

Tavoloni, N.; Schaffner, F

Acknowledgement 136

No. 3 Original Paper

Cell Proliferation during Morphogenesis of the Human Colon

Arsenault, P.; Ménard, D 137

Extracellular Volume of the Human Placenta in vitro

Lear, G.H.; Barker, G.; Sibley, C.P.; Boyd, R.D.H 143

Stimulation by $17 \alpha$-Hydroxyprogesterone of Glycoprotein and Glycosaminoglycan Synthesis in Human Placenta in vitro

Burton, A.; Lockhart, F.; Bosnjak, S.; Yong, S 151

Fc and Complement Receptor (CR1 and CR3) Expression on Neonatal Human Polymorphonuclear Leukocytes

Fleit, H.B 156

Presence of a Diurnal Rhythm in Fetal Prolactin Secretion and Influence of Maternal Nutrition

Bassett, N.S.; Bennet, L.; Ball, K.T.; Gluckman, P.D

164

Sensitivity of the Renal Adenylate Cyclase Receptor System to Parathormone during the

Last Third of Pregnancy in the Rat

Gugi, B.; Mallet, E 171

Cholesterol Metabolism in Infant Rats, Effect of 6-Hydroxydopamine and Guanfacine

Hahn, P.; Srubitski, L 180

Acyl-CoA Dehydrogenase Enzymes during Early Postnatal Development in the Rat

Carroll, J.E.; McGuire, B.S.; Chancey, V.F.; Harrison, K.B 185

Effect of Light and Hyperoxia on Ocular Blood Flow in the Newborn Piglet

Stiris, T.; Hansen, T.W.R.; Odden, J.-P.; Mørkrid, L.; Bratlid, D 191

Aono/Semba/Sato/Kashiwamata

Plate I 


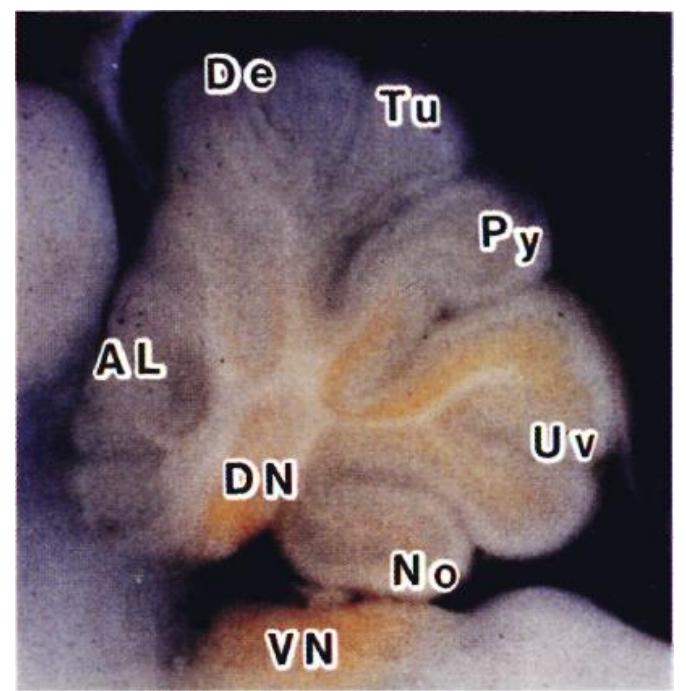

Fig. 1. A typical example of bilirubin deposition in the cerebellum of a 15-day-old jaundiced Gunn rat $24 \mathrm{~h}$ after bucolome treatment. Localized yellow staining is most apparent in the granule cell layer of the ventral part of the pyramis (Py) and the dorsal part of the uvula (Uv), and also in the deep nuclear region (DN). A highly pigmented noncerebellar brain part is the vestibular nuclear region $(\mathrm{VN})$. Other explanations are given in the text. $\mathrm{AL}=$ Anterior lobe; De $=$ declive; $\mathrm{Tu}=$ tuber; $\mathrm{No}=$ nodulus. For experimental details see 'Materials and Methods'.

Biol Neonate, Vol. 55

S. Karger, Basel

Contents V

No. 4-5 Original Paper

Cholinergic Responsiveness of Goblet Cells during Intestinal Maturation

Phillips, T.E.; Phillips, T.L.; Neutra, M.R 197

Low Intestinal Lactase Activity in Offspring from Ethanol-Treated Mothers

López-Tejero, D.; Arilla, E.; Colas, B.; Llobera, M.; Herrera, E 204

Trace Elements in Meconium from Preterm and Full-Term Infants

Friel, J.K.; Matthew, J.D.; Andrews, W.L.; Skinner, C.T 214

Congenital Hypothyroidism: Decreased Growth Velocity in the First Weeks of Life

Leger, J.; Czernichow, P 218

Free Tryptophan Decrease in Jaundiced Newborn Infants during Phototherapy

Zammarchi, E.; La Rosa, S.; Pierro, U.; Lenzi, G.; Bartolini, P.; Falorni, S 224

Posttransfusion Hemoglobinuria and Myoglobinuria in Neonates

Zanardo, V.; Foti, P.; Marioni, L.; Andrian, C; Pornaro, E.; Zacchello, G 228

Urinary and Blood Levels of Adenosine 3',5'-Monophosphate, Phosphorus and Calcium in Infants

Weintraub, Z.; Iancu, T.C.; Sheinfeld, M.; Kraiem, Z

Influence of Adrenalectomy on the Development of the Neonatal Thymus in the Rat Inomata, T.; Nakamura, T 238

Daily Sequential Changes in Plasma Atrial Natriuretic Factor Concentrations in Mechanically Ventilated Low-Birth-Weight Infants. Effect of Surfactant Replacement

Liechty, E.A.; Johnson, M.D.; Myerberg, D.Z.; Mullett, M.D 244

Morphological Changes in the Placentas of Smoking Mothers: A Histomorphometric Study 
Teasdale, F.; Ghislaine, J.-J 251

Cerebrospinal Fluid Concentrations of Neurotensin and Corticotropin-Releasing Factor in Pediatric Patients

Hedner, J.; Hedner, T.; Lundell, K.-H.; Bissette, G.; O’Connor, L.; Nemeroff, C.B. . 260 Effects of Early Postnatal Undernutrition on Brainstem Auditory Evoked Potentials in

Weanling Rats

Kawai, S.; Nakamura, H.; Matsuo, T 268

Cerebral Blood Flow and Metabolism in Fasting Neonatal Piglets

Flecknell, P.A.; Wootton, R 275

Cerebral Metabolic Response and Mitochondrial Activity following Insulin-Induced Hypo-

glycemia in Newborn Lambs

Belik, J.; Wagerle, L.C.; Stanley, C.A.; Sacks, L.M.; Herbert, D.W.; Delivoria-Papado-

poulos, M 281

Partitioning and Extraction of Glucose Regulates Cerebral Glucose Utilization in Newborn

Dogs

Huang, M.M.E.; ICliegman, R.M.; Chau, K 290

Maternal and Fetal Endocrine Pancreas in the Spontaneously Diabetic BB Rat

Verhaeghe, J.; Peeters, T.L.; Vandeputte, M.; Rombauts, W.; Bouillon, R.; Van Assche, F.A. 298

Comparison of Renal Function in Term Fetal Sheep and Newborn Lambs

Smith, F.G.; Lumbers, E.R 309

No. 6 Developmental Physiology: A Tribute to the Influence of Alfred Jost

Foreword

Girard, G 321

Sexual Differentiation of the Gonads and of the Reproductive Tract

Wilson, J.D 322

Endocrine Control of Fetal Growth

Browne, C.A.; Thorburn, G.D 331

An Update of Fetal and Placental Metabolism: Carbohydrate and Amino Acids

Battaglia, F.C 347

Solute and Water Transport across the Pulmonary Epithelium: A New Chapter in Lung

Physiology Inaugurated by Alfred Jost

Strang, L.B 355

Initiation of Labour

Liggins, G.C 366

Thyroid Hormones and Nervous System Development

Timiras, P.S.; Nzekwe, E.U 376

Author Index 386

Subject Index 388 